\title{
THE SHARE OF CROSS-BORDER SHOPPING IN POLAND'S TRADE TURNOVER OF FOOD PRODUCTS WITH NEIGHBOURING COUNTRIES ON THE EUROPEAN UNION EASTERN BORDER IN 2013-2018
}

\author{
Halina Powęska ${ }^{\bowtie}$ \\ Warsaw University of Life Sciences - SGGW, Poland
}

\begin{abstract}
Trade turnover of food products between Poland and its neighbouring countries on the external eastern border of the European Union (Ukraine, Belarus and Russia) is an important element of the international trade exchange of Poland. The registered trade turnover had an impact on the Polish economy, whereas, from the point of view of development of areas located within the border impact zone, the unregistered trade that is part of cross-border shopping was of great importance. The aim of the paper is to examine the dynamics and trends of changes in terms of the share of cross-border shopping in the total trade turnover of food products with the above-mentioned countries over the period 2013-2018. A case study analysis conducted in all three countries showed that there was a steady increase in the share of unregistered trade in the total trade volume throughout the entire research period.
\end{abstract}

Key words: food products, cross-border trade on the Polish eastern border, foreign trade

JEL codes: E26, F14, F31

\section{INTRODUCTION}

A phenomenon accompanying international travels is the carrying of small quantities of goods (unregistered in the customs clearance documents) purchased by citizens in a country other than where they live. The phenomenon called cross-border shopping occurs on border sections where it is possible for people to move across the border, and where price differences and the quality of goods, as well as the level of supply in the neighbouring markets, are so high that the difficulties faced by the travellers in transporting goods to the neighbouring country can be economically compensated [Baruca and Zolfagharian 2015, Egresi and Arlstan 2016, Powęska 2016, Bygvra 2019].
Through the fact of buying and selling between the business entities located in the neighbouring countries, establishing international trade relations and the transfer of goods across the border, unregistered purchases made as part of cross-border shopping can be classified as part of international trade turnover, thus having some influence on its total volume [Rymarczyk 2017]. The dominant place of purchase and sale acts are bazaars and marketplaces, which from the theoretical point of view are classified as organized defective markets [Dudziński 2006]. At the same time, it should be noted that transactions made over the course of cross-border shopping are relatively low-value transactions. There are formal and legal differences between registered and unregistered trade; foremostly, 
Powęska, H. (2020). The share of cross-border shopping in Poland's trade turnover of food products with neighbouring countries on the European Union eastern border in 2013-2018. Acta Sci. Pol. Oeconomia 19 (4), 103-112, DOI: 10.22630/ASPE.2020.19.4.46

the purpose of the transport of unregistered goods is to provide commodities to natural persons and their families, while in the registered trade, goods are carried in bulk quantities and they are further put into circulation on the market of a given country.

The effect of an increase in the volume of cross-border shopping is the development of some social and economic functions, primarily the growth of trade [Cyrek and Cyrek 2019]. Cross-border shopping plays a particularly important role in the regions located in the direct impact zone of the border, first of all in those areas where there are border crossings. Among citizens living at a distance of up to $30 \mathrm{~km}$ from the border line, purchases are very often the main reason for making a trip to a neighbouring country. Citizens coming from a neighbouring country to make purchases have a positive influence on the local market, primarily by increasing demand, stimulating local entrepreneurship and increasing the level of production, which consequently leads to the creation of new jobs. Therefore, cross-border shopping is treated by the communities of the peripheral self-government units, which are located at the border, as a stimulator of socio-economic development. On the other hand, there is a phenomenon of disregarding the norms and tariffs in terms of the amount of goods allowed to be transported across the border, which is why it is difficult to separate legal cross-border shopping from illegal trading activities (smuggling).

In the areas remaining in the impact zone of the Polish section of the external eastern border of the European Union, agriculture is an important socio-economic function, since agricultural production is of interest to the citizens of neighbouring countries who cross the border in order to make purchases. Taking all this into consideration, the main purpose of the paper is to examine the dynamics and trends of changes in the share of cross-border shopping in the total volume of trade turnover of food products in Poland's trade with the above-mentioned countries as well as to determine the value and share of food items in Poland's trade relations with eastern neighbours, that is to say Ukraine, Belarus and Russia, during the period 2013-2018. The paper is a continuation of the research carried out for the years 2010-2012 [Powęska 2014], which is why its summary shows the differences between these two research periods.

\section{RESEARCH METHODOLOGY AND SOURCES}

Food products are often the main reason for crossing the border, and the most common destination of the shopping trips are commercial outlets situated in convenient locations in relation to the border crossing. This also takes place on the Polish section of the external border of the European Union. Thus, when citizens carry unregistered goods purchased abroad to their country of residence, they contribute to an increase in international trade turnover. Taking this into consideration, the following research questions were formulated in the study: what were the changes in the share of cross-border shopping (unregistered purchases) in the total volume of international trade turnover (registered and unregistered sectors, as well as services registered in the EBOPS system in total) of food products over the period 2013-2018 on the Polish section of the EU external border. By analysing the phenomenon for individual years, the trends of changes in the adopted research period were shown, and, taking into account the results of previous studies, long-term trends were indicated. The analysis was supplemented with characteristics of the dynamics in the pattern of registered foreign trade in food products. At both levels of analysis, the research on the exports and imports of goods was carried out separately.

Data relating to the value and pattern of cross-border trade was taken from the publication of the Centre of the Cross-border Areas Surveys and Statistics for Euroregions (Ośrodek Badań Obszarów Transgranicznych i Statystyki Euroregionalnej), which is a part of the Statistical Office in Rzeszów (Urząd Statystyczny w Rzeszowie) [GUS - US Rzeszów 2014, 2015, 2016, 2017, 2018, 2019], while the data on foreign trade registered in the customs clearance documents was available in the Yearbooks of Foreign Trade Statistics of the Statistics Poland (Główny Urząd Statystyczny) [GUS 2014, 2015, 2016, 2017, 2018, 2019].

For individual years covered by the study, the total volume of Poland's trade turnover with eastern neighbours was calculated by summing up the registered and unregistered turnover. In the registered turnover, both in exports and imports, the values of goods registered in customs clearance documents as well as expenses for services recorded in the EBOPS system were taken into consideration. Expenses for purchased services 
Powęska, H. (2020). The share of cross-border shopping in Poland's trade turnover of food products with neighbouring countries on the European Union eastern border in 2013-2018. Acta Sci. Pol. Oeconomia 19 (4), 103-112, DOI: 10.22630/ASPE.2020.19.4.46

were added to the Polish imports, while the value of the services provided was added to the Polish exports. The value of goods transported across the border as part of cross-border shopping was treated as unregistered turnover. In subsequent stages of the study, based on the statistical analysis, an assessment was made of: (1) the share of food products in unregistered turnover; (2) percentage of food products in the registered import and export to the particular countries; and (3) comparison of the registered and unregistered sector in the turnover of food products between Poland and each of the neighbouring countries at the external border of the EU. In addition, in the next part of the study an assessment was made of the value and commodity structure of the registered trade in food products with individual countries.

\section{THE SHARE OF CROSS-BORDER SHOPPING IN POLAND'S FOOD PRODUCTS EXPORT TO NEIGHBOURING COUNTRIES ON THE EU EXTERNAL BORDER IN 2013-2018}

In the years 2013-2018, there were diverse trends in the value and share of the food sector in Poland's exports to the individual countries located along the external border of the European Union (Table 1). In the case of Ukraine, there was an increase in unregistered exports, both in terms of the total volume of goods and in the value of foodstuffs.

The share of food commodities in the structure of unregistered exports tended to decline (from $12 \%$ to $11 \%$ ), which points to the increasing dynamics of the unregistered export of non-food products. However, in the case of Russia, on the border with the Kaliningrad Region (Oblast), there was a slight decrease in the absolute value of unregistered turnover, both in the total volume of goods and in the value of foodstuffs. The share of food expenses in unregistered exports fell from $33 \%$ to $26 \%$ during this period. However, in the case of Belarus, the share of food products in cross-border shopping varied and it oscillated around $11-13 \%$, remaining at the level of the highest values at the beginning and at the end of the research period.

As regards registered exports in terms of absolute value, trends varied greatly between individual countries. In the case of Ukraine, the values of registered exports to Ukraine varied with slight upward trends (from PLN 1.9 PLN billion in 2013 to PLN 2.1 billion in 2018), with the lowest value being recorded for the year 2015, when the value of foodstuffs exported to Ukraine amounted to PLN 1.2 billion. In the case of Belarus, throughout the research period the absolute value of registered exports remained at a similar level with a slightly decreasing trend (from PLN 1.2 billion in 2013 to around PLN 1 billion in 2018). However, in the case of Russia, this decline was more marked (from PLN 5.2 billion to PLN 2.1 billion).

When analysing the share of cross-border shopping in the total value of food sales, in the case of all three countries, an increase in the share of unregistered sales was recorded. The largest share and growth dynamics took place in Poland's trade relations with Ukraine (increase from $22.7 \%$ to $28.8 \%$ ). In the case of Belarus the share of unregistered trade in foodstuffs in the total volume of trade in these items remained at a similar level (it totalled from $24.9 \%$ in 2013 to $25.4 \%$ in 2018). However, in the case of Russia the share of unregistered trade in food products increased from $3.6 \%$ in 2013 to $6.3 \%$ in 2018 .

Most purchases of food items were made by foreigners who were cross-border shoppers on the PolishUkrainian border (from around PLN 560 million in 2013 to more than PLN 830 million in 2018). Despite the increase in the absolute value of sales within the cross-border trade, there was a decrease in the share of food products in unregistered sales, which indicates that during this period non-food products, including alcohol and industrial products, became increasingly important. On the Polish-Belarusian border there was a decrease in the absolute value of goods exported from Poland by foreigners (from around PLN 400 billion in 2013 to PLN 330 million in 2018); at the same time, the share of food products remained unchanged and amounted to some $13 \%$ throughout the research period, which allows us to conclude that the value of industrial goods and alcohol decreased in favour of food products. As regards Russia, the value of the goods exported in an unregistered manner decreased during the period under consideration from almost PLN 200 million to PLN 140 million. Similar trends were observed in the share of food products in unregistered trade (decrease from $33 \%$ to $26 \%$ ). However, the importance of industrial goods in unregistered turnover increased significantly on this border section. 
Powęska, H. (2020). The share of cross-border shopping in Poland's trade turnover of food products with neighbouring countries on the European Union eastern border in 2013-2018. Acta Sci. Pol. Oeconomia 19 (4), 103-112, DOI: 10.22630/ASPE.2020.19.4.46

Table 1. Share of food items in Poland's exports to eastern neighbours while taking into account the unregistered sector (cross-border shopping) and the registered sector (the values of goods registered in customs clearance documents and EBOPS) in the years 2013-1018

\begin{tabular}{|c|c|c|c|c|c|c|c|c|}
\hline \multirow{3}{*}{ Year } & \multicolumn{3}{|c|}{$\begin{array}{c}\text { Expenditures in Poland of cross-border } \\
\text { shoppers from neighbouring countries } \\
\text { on the Polish section of the EU eastern } \\
\text { border }\end{array}$} & \multicolumn{3}{|c|}{$\begin{array}{l}\text { Export value from Poland (the values } \\
\text { of goods registered in customs clearance } \\
\text { documents) and the value of services delivered } \\
\text { by Poland (EBOPS) to neighbouring countries } \\
\text { on the Polish section of the EU eastern border }\end{array}$} & \multicolumn{2}{|c|}{$\begin{array}{l}\text { Unregistered expenditures } \\
\text { of foreign consumers in Poland on } \\
\text { food items (cross-border shopping) } \\
\text { and Poland's exports of food } \\
\text { items to neighbouring countries } \\
\text { in customs clearance documents }\end{array}$} \\
\hline & \multirow{2}{*}{$\begin{array}{c}\text { total } \\
\text { thous. PLN }\end{array}$} & \multicolumn{2}{|c|}{$\begin{array}{l}\text { of which expenditures } \\
\text { on food commodities }\end{array}$} & total & \multicolumn{2}{|c|}{ share of food items } & \multirow{2}{*}{$\begin{array}{c}\text { share of cross- } \\
\text {-border shopping } \\
\text { in Poland's sales } \\
\text { of food items } \\
\%\end{array}$} & \multirow{2}{*}{$\begin{array}{c}\text { share of food } \\
\text { items in sales } \\
\text { to neighbouring } \\
\text { countries }\end{array}$} \\
\hline & & thous. PLN & $\%$ of total & thous. PLN & thous. PLN & $\%$ of total & & \\
\hline 1 & 2 & 3 & 4 & 5 & 6 & 7 & 8 & 9 \\
\hline \multicolumn{9}{|c|}{ Ukraine } \\
\hline 2018 & 7481067.3 & 830135.0 & 11.10 & 32809363.5 & 2056270.0 & 6.27 & 28.76 & 7.16 \\
\hline 2017 & 7699057.8 & 852301.2 & 11.07 & 18184917.4 & 1721458.0 & 9.47 & 33.12 & 9.94 \\
\hline 2016 & 7148199.2 & 764653.9 & 10.70 & 15059264.4 & 1419767.0 & 9.43 & 35.00 & 9.84 \\
\hline 2015 & 6483253.4 & 682943.5 & 10.53 & 12446346.7 & 1245464.0 & 10.01 & 35.41 & 10.19 \\
\hline 2014 & 5679321.0 & 762674.9 & 13.43 & 17768319.3 & 1496402.0 & 8.42 & 33.76 & 9.63 \\
\hline 2013 & 4616050.1 & 563130.3 & 12.20 & 24342306.2 & 1910940.0 & 7.85 & 22.76 & 8.54 \\
\hline \multicolumn{9}{|c|}{ Belarus } \\
\hline 2018 & 2431662.3 & 334196.7 & 13.74 & 6133739.4 & 982883.6 & 16.02 & 25.37 & 15.38 \\
\hline 2017 & 2458702.7 & 333039.8 & 13.55 & 5634093.8 & 1262356.0 & 22.41 & 20.88 & 19.71 \\
\hline 2016 & 2328802.1 & 299278.6 & 12.85 & 5312009.1 & 1454516.0 & 27.38 & 17.06 & 22.95 \\
\hline 2015 & 2555248.2 & 307856.2 & 12.05 & 4997068.4 & 974393.3 & 19.50 & 24.01 & 16.98 \\
\hline 2014 & 3101506.5 & 338423.7 & 10.91 & 10263504.7 & 1141534.0 & 11.12 & 22.87 & 11.07 \\
\hline 2013 & 2972772.3 & 406379.5 & 13.67 & 11699565.4 & 1223236.0 & 10.46 & 24.94 & 11.11 \\
\hline \multicolumn{9}{|c|}{ Russia } \\
\hline 2018 & 552159.8 & 143841.1 & 26.05 & 33262998.2 & 2154770.0 & 6.48 & 6.26 & 6.80 \\
\hline 2017 & 568765.3 & 149826.7 & 26.34 & 30186231.0 & 1969410.0 & 6.52 & 7.07 & 6.89 \\
\hline 2016 & 484287.3 & 130923.1 & 27.03 & 26566878.2 & 1606976.0 & 6.05 & 7.53 & 6.42 \\
\hline 2015 & 581922.7 & 165656.9 & 28.47 & 25388139.6 & 1669076.0 & 6.57 & 9.03 & 7.06 \\
\hline 2014 & 842417.9 & 204292.8 & 24.25 & 34164847.4 & 3679519.0 & 10.77 & 5.26 & 11.09 \\
\hline 2013 & 583922.8 & 196517.4 & 33.65 & 39242372.8 & 5255260.0 & 13.39 & 3.60 & 13.69 \\
\hline
\end{tabular}

Column 8 calculated by equation $[3:(3+6)] \cdot 100$; Column 9 calculated by equation $[(3+6):(2+5)] \cdot 100$.

Source: Author's own elaboration based on Yearbooks of Foreign Trade Statistics of Poland of the period 2014-2019 [GUS 2014, 2015, 2016, 2017, 2018, 2019] and annual reports on turnover of goods and services in border traffic on the EU external border in Poland in the period 2013-2018 [GUS - US Rzeszów 2014, 2015, 2016, 2017, 2018, 2019]. 
Powęska, H. (2020). The share of cross-border shopping in Poland's trade turnover of food products with neighbouring countries on the European Union eastern border in 2013-2018. Acta Sci. Pol. Oeconomia 19 (4), 103-112, DOI: 10.22630/ASPE.2020.19.4.46

Unregistered purchases of food products in Poland made by foreign consumers crossing the external eastern EU border into Poland are an important supplement to registered sales made as part of exports. With the entire spectrum of political conditions ${ }^{1}$ adversely affecting trade relations with the East, the share of unregistered trade increased during the entire research period, which positively influenced business relations and which was important for Polish agriculture. This was of particular importance in relation to Ukraine, where there was an increase in the absolute value of unregistered expenses for food products throughout the entire research period.

One should point to the commodity pattern of the registered export of food products (Table 2), which is very diverse depending on the country. In the case of

Table 2. The value and structure of exports of food products registered in customs clearance documents from Poland to neighbouring countries on the Polish section of the EU external border

\begin{tabular}{|c|c|c|c|c|c|c|c|c|c|c|}
\hline \multirow{2}{*}{ Year } & \multicolumn{2}{|c|}{$\begin{array}{l}\text { Live animals and animal } \\
\text { products }\end{array}$} & \multicolumn{2}{|c|}{ Vegetable products } & \multicolumn{2}{|c|}{ Prepared foodstuffs } & \multicolumn{2}{|c|}{ Fats and oils } & \multicolumn{2}{|c|}{ Total food products } \\
\hline & thous. PLN & $\begin{array}{l}\% \text { of } \\
\text { total }\end{array}$ & thous. PLN & $\begin{array}{l}\% \text { of } \\
\text { total }\end{array}$ & thous. PLN & $\begin{array}{l}\% \text { of } \\
\text { total }\end{array}$ & thous. PLN & $\begin{array}{l}\% \text { of } \\
\text { total }\end{array}$ & thous. PLN & $\begin{array}{l}\% \text { of } \\
\text { total }\end{array}$ \\
\hline \multicolumn{11}{|c|}{ Ukraine } \\
\hline 2018 & 504742.1 & 24.55 & 425219.9 & 20.68 & 1108212.1 & 53.89 & 18095.7 & 0.88 & 2056269.8 & 100.00 \\
\hline 2017 & 406393.7 & 23.61 & 470181.9 & 27.31 & 829047.3 & 48.16 & 15835.1 & 0.92 & 1721458.0 & 100.00 \\
\hline 2016 & 309581.5 & 21.81 & 379686.7 & 26.74 & 720237.4 & 50.73 & 10261.1 & 0.72 & 1419766.7 & 100.00 \\
\hline 2015 & 269379.5 & 21.63 & 395431.8 & 31.75 & 565860.5 & 45.43 & 14791.8 & 1.19 & 1245463.6 & 100.00 \\
\hline 2014 & 328242.2 & 21.94 & 521970.8 & 34.88 & 639772.2 & 42.75 & 6416.5 & 0.43 & 1496401.7 & 100.00 \\
\hline 2013 & 492024.7 & 25.75 & 678462.3 & 35.50 & 730197.6 & 38.21 & 10255.4 & 0.54 & 1910940.0 & 100.00 \\
\hline \multicolumn{11}{|c|}{ Belarus } \\
\hline 2018 & 85602.5 & 8.71 & 721834.8 & 73.44 & 171224.6 & 17.42 & 4221.7 & 0.43 & 982883.6 & 100.00 \\
\hline 2017 & 54751.7 & 4.34 & 1034273.6 & 81.93 & 173330.9 & 13.73 & - & - & 1262356.2 & 100.00 \\
\hline 2016 & 210314.0 & 14.46 & 1100922.1 & 75.69 & 143280.2 & 9.85 & - & - & 1454516.3 & 100.00 \\
\hline 2015 & 144083.5 & 14.79 & 681102.4 & 69.90 & 147664.2 & 15.15 & 1543.2 & 0.16 & 974393.3 & 100.00 \\
\hline 2014 & 181183.4 & 15.87 & 797693.6 & 69.88 & 160438.4 & 14.05 & 2218.7 & 0.19 & 1141534.1 & 100.00 \\
\hline 2013 & 554685.4 & 45.35 & 513009.6 & 41.94 & 155541.1 & 12.72 & - & - & 1223236.1 & 100.00 \\
\hline \multicolumn{11}{|c|}{ Russia } \\
\hline 2018 & 12135.4 & 0.56 & 276844.7 & 12.85 & 1830441.1 & 84.95 & 35348.6 & 1.64 & 2154769.8 & 100.00 \\
\hline 2017 & 7470.4 & 0.38 & 270858.5 & 13.75 & 1644545.8 & 83.50 & 46534.8 & 2.36 & 1969409.5 & 100.00 \\
\hline 2016 & 46431.0 & 2.89 & 252119.6 & 15.69 & 1308425.0 & 81.42 & - & - & 1606975.6 & 100.00 \\
\hline 2015 & 57412.3 & 3.44 & 249243.4 & 14.93 & 1334575.8 & 79.96 & 27844.0 & 1.67 & 1669075.5 & 100.00 \\
\hline 2014 & 548214.1 & 14.90 & 1399576.3 & 38.04 & 1708507.6 & 46.43 & 23220.9 & 0.63 & 3679518.9 & 100.00 \\
\hline 2013 & 1350771.5 & 25.70 & 2336708.8 & 44.46 & 1548055.0 & 29.46 & 19725.1 & 0.38 & 5255260.4 & 100.00 \\
\hline
\end{tabular}

Source: Author's own elaboration based on Yearbooks of Foreign Trade Statistics of Poland of the period 2014-2019 [GUS 2014, 2015, 2016, 2017, 2018, 2019].

\footnotetext{
${ }^{1}$ On 7 August 2014, the Russian government introduced a ban on the imports of some agricultural products, including fruits and vegetables, from the European Union to the Russian Federation. In June 2015, the Russian authorities decided to continue the embargo until August 2016. On 29 June 2016, the ban was extended until the end of 2017, while in June 2017 - till the end of 2018.
} 
Powęska, H. (2020). The share of cross-border shopping in Poland's trade turnover of food products with neighbouring countries on the European Union eastern border in 2013-2018. Acta Sci. Pol. Oeconomia 19 (4), 103-112, DOI: 10.22630/ASPE.2020.19.4.46

Ukraine, over the period analysed there was a decline in the share of plant products and an increase in food preserves. Nevertheless, the share of live animals and animal products remained at a similar level in the period under consideration. In the case of Belarus, during the period analysed there was a decline in the share of live animals and animal products as well an increase in plant products, while food preserves remained at a similar level throughout the considered period. In the case of Russia, during the period under consideration there was a decrease in the share of live animals and animal products, as well as of plant products, while a clear increase was noted with regard to food preserves. Trends in export dynamics were the reflection of political conditions.

\section{THE SHARE OF CROSS-BORDER SHOPPING IN FOOD PRODUCTS IMPORT TO POLAND FROM NEIGHBOURING COUNTRIES ON THE EU EXTERNAL BORDER IN 2013-2018}

In the years 2013-2018, varied trends were noted in the value and share of the food sector in Poland's imports from, neighbouring countries located at the external eastern border of the European Union (Table 3). In the case of Ukraine, there was a drop in the value of unregistered imports, both in the total volume of goods and in the value of foodstuffs. Yet the share of food products in the structure of unregistered purchases tended to increase (from $10 \%$ to $11 \%$ ), which indicates that declines in the value of unregistered purchases of industrial goods were greater than those recorded in the case of food products. Similar trends were noted with regard to Russia. During the period 2013-2018, there was a clear drop in the value of unregistered purchases, both in the total volume of goods and in the group of food products. At the same time, there was an increase in the share of food products in the general structure of unregistered purchases made by Polish citizens in Russia (mainly in the Kaliningrad Oblast), which indicates that declines in the value of non-food products were greater than those in the value of foodstuffs. In the case of Belarus, there was an increase in both the absolute value of the total volume of goods brought by cross-border shoppers and in the value of food products brought to Poland. The share of food expenses in unreg- istered purchases increased from $3 \%$ to $5.5 \%$ during this period. It is worth noting that regardless of the trends in the absolute value of unregistered purchases, in the case of all three countries there was an increase in the share of food products in the pattern of cross-border trade.

As regards the imports registered in custom clearance documents, in terms of the absolute value the trends varied widely between individual countries. In the case of Ukraine, a steady upward trend was recorded (from PLN 1.4 billion in 2013 to PLN 2.4 billion in 2018). Throughout the entire research period, the share of food products in the registered trade with Poland's south-eastern neighbour was at the level of $18-21 \%$, with the highest rates recorded in the years 2015-2016 (over 20\%), and with the lowest rates noted in the years 2013-2014 (17-18\%). In the case of Belarus and Russia, the share of food products recorded in the customs clearance documents was much lower and totalled around $2 \%$ and $1 \%$, respectively. As regards the value of the registered import of food products from these countries to Poland, an upward trend was recorded. In addition, in relation to the total value of imports, food products took low import positions.

By treating food imports with the countries neighbouring Poland in the east as the total value of the registered imports as well as of unregistered purchases made by cross-border shoppers, we can point out that the greatest share of foodstuffs was noted on the border with Ukraine; it totalled from $17 \%$ to $21 \%$, and in the years 2013-2018 it grew slowly, while from 2015 to 2018, there was a downward trend. However, the imports of food products from Belarus and Russia were relatively smaller, and the share of this group of commodities amounted to $2 \%$ and $0.5-1 \%$, respectively. The share of cross-border shopping in the import of goods was the highest on the border with Belarus, and it was slightly smaller, even minimal, on the border with Ukraine and Russia.

In the structure of the import of food products to Poland from neighbouring countries on the external section of the eastern border of the European Union, registered in customs clearance documents (Table 4), the relatively highest values were recorded in trade with Ukraine. Plant products played an important role in this field, although during the period under consideration their share tended to decline from almost 50\% 
Powęska, H. (2020). The share of cross-border shopping in Poland's trade turnover of food products with neighbouring countries on the European Union eastern border in 2013-2018. Acta Sci. Pol. Oeconomia 19 (4), 103-112, DOI: 10.22630/ASPE.2020.19.4.46

Table 3. Share of food items in Poland's imports from eastern neighbours while taking into consideration the unregistered sector (cross-border shopping) and the registered sector (the values of goods registered in customs clearance documents and EBOPS) in the years 2013-1018

Expenditures of Polish cross-border shoppers in neighbouring countries on the Polish section of the EU eastern border
Imports of Polish goods registered in customs clearance documents and expenditures on services purchased by Polish citizens (EBOPS) in neighbouring countries on the Polish section of the EU eastern border
Unregistered Polish consumer expenditures on food items in neighbouring countries on the Polish section of the EU eastern border (cross-border shopping) and Poland's imports of food items from neighbouring countries in customs clearance documents

Year of which food items

total of which food items share of cross-

-border shopping

in Poland's

imports of non-

-food items from

neighbouring

countries

\begin{tabular}{|c|c|c|c|c|c|c|c|c|}
\hline & thous. PLN & thous. PLN & $\begin{array}{l}\% \text { of } \\
\text { total }\end{array}$ & thous. PLN & thous. PLN & $\begin{array}{l}\% \text { of } \\
\text { total }\end{array}$ & $\%$ & $\%$ \\
\hline 1 & 2 & 3 & 4 & 5 & 6 & 7 & 8 & 9 \\
\hline \multicolumn{9}{|c|}{ Ukraine } \\
\hline 2018 & 205143.4 & 22586.2 & 11.01 & 12711417.8 & 2429905.1 & 19.12 & 0.92 & 18.99 \\
\hline 2017 & 212596.5 & 22619.9 & 10.64 & 11025435.8 & 2170821.3 & 19.69 & 1.03 & 19.52 \\
\hline 2016 & 225615.8 & 23749.6 & 10.53 & 9314528.2 & 1919892.4 & 20.61 & 1.22 & 20.37 \\
\hline 2015 & 213781.9 & 23099.0 & 10.80 & 7513637.1 & 1605988.0 & 21.37 & 1.42 & 21.08 \\
\hline 2014 & 203267.4 & 21344.0 & 10.50 & 8045023.2 & 1506714.4 & 18.73 & 1.40 & 18.53 \\
\hline 2013 & 241338.0 & 24203.9 & 10.03 & 8244281.6 & 1463457.3 & 17.75 & 1.63 & 17.53 \\
\hline \multicolumn{9}{|c|}{ Belarus } \\
\hline 2018 & 93329.4 & 5100.4 & 5.46 & 7781991.5 & 142555.7 & 1.83 & 3.45 & 1.87 \\
\hline 2017 & 91468.0 & 4881.7 & 5.34 & 5572296.9 & 57004.4 & 1.02 & 7.89 & 1.09 \\
\hline 2016 & 79065.2 & 4232.9 & 5.35 & 3714238.2 & 51336.8 & 1.38 & 7.62 & 1.46 \\
\hline 2015 & 79042.7 & 4254.0 & 5.38 & 7130187.5 & 84291.4 & 1.18 & 4.80 & 1.23 \\
\hline 2014 & 90432.8 & 4739.3 & 5.24 & 3213878.5 & 36124.0 & 1.12 & 11.60 & 1.24 \\
\hline 2013 & 79535.6 & 2463.9 & 3.10 & 3072770.1 & 63209.2 & 2.06 & 3.75 & 2.08 \\
\hline \multicolumn{9}{|c|}{ Russia } \\
\hline 2018 & 206394.2 & 4563.4 & 2.21 & 74294374.9 & 530697.0 & 0.71 & 0.85 & 0.72 \\
\hline 2017 & 224865.6 & 4492.3 & 2.00 & 58290292.2 & 343686.7 & 0.59 & 1.29 & 0.60 \\
\hline 2016 & 283008.9 & 3912.8 & 1.38 & 46825223.8 & 637315.9 & 1.36 & 0.61 & 1.36 \\
\hline 2015 & 443803.5 & 6067.6 & 1.37 & 55506576.0 & 751323.9 & 1.35 & 0.80 & 1.35 \\
\hline 2014 & 454722.2 & 6556.5 & 1.44 & 74793888.6 & 673159.1 & 0.90 & 0.96 & 0.90 \\
\hline 2013 & 377539.5 & 7309.9 & 1.94 & 81728469.9 & 376067.0 & 0.46 & 1.91 & 0.47 \\
\hline
\end{tabular}

Column 8 calculated by equation $[3:(3+6)] \cdot 100$; Column 9 calculated by equation $[(3+6):(2+5)] \cdot 100$.

Source: Author's own elaboration based on Yearbooks of Foreign Trade Statistics of Poland of the period 2014-2019 [GUS 2014, 2015, 2016, 2017, 2018, 2019] and annual reports on turnover of goods and services in border traffic on the EU external border in Poland in the period 2013-2018 [GUS - US Rzeszów 2014, 2015, 2016, 2017, 2018, 2019 ]. 
Powęska, H. (2020). The share of cross-border shopping in Poland's trade turnover of food products with neighbouring countries on the European Union eastern border in 2013-2018. Acta Sci. Pol. Oeconomia 19 (4), 103-112, DOI: 10.22630/ASPE.2020.19.4.46

Table 4. The value and structure of imports of food products as registered in customs clearance documents from Poland to neighbouring countries on the Polish section of the EU external border

\begin{tabular}{|c|c|c|c|c|c|c|c|c|c|c|}
\hline \multirow{2}{*}{ Year } & \multicolumn{2}{|c|}{$\begin{array}{c}\text { Live animals and animal } \\
\text { products }\end{array}$} & \multicolumn{2}{|c|}{ Vegetable products } & \multicolumn{2}{|c|}{ Prepared foodstuffs } & \multicolumn{2}{|c|}{ Fats and oils } & \multicolumn{2}{|c|}{ Total food products } \\
\hline & thous. PLN & $\begin{array}{l}\% \text { of } \\
\text { total }\end{array}$ & thous. PLN & $\begin{array}{l}\% \text { of } \\
\text { total }\end{array}$ & thous. PLN & $\begin{array}{l}\% \text { of } \\
\text { total }\end{array}$ & thous. PLN & $\begin{array}{l}\% \text { of } \\
\text { total }\end{array}$ & thous. PLN & $\begin{array}{l}\% \text { of } \\
\text { total }\end{array}$ \\
\hline \multicolumn{11}{|c|}{ Ukraine } \\
\hline 2018 & 304331.9 & 12.5 & 855756.2 & 35.2 & 721004.3 & 29.7 & 548812.7 & 22.6 & 2429905.1 & 100.0 \\
\hline 2017 & 155347.0 & 7.2 & 767384.3 & 35.3 & 683722.4 & 31.5 & 564367.6 & 26.0 & 2170821.3 & 100.0 \\
\hline 2016 & 119971.0 & 6.2 & 838128.8 & 43.7 & 613991.3 & 32.0 & 347801.3 & 18.1 & 1919892.4 & 100.0 \\
\hline 2015 & 72221.1 & 4.5 & 717443.1 & 44.7 & 600004.5 & 37.4 & 216319.3 & 13.5 & 1605988.0 & 100.0 \\
\hline 2014 & 86032.6 & 5.7 & 724878.7 & 48.1 & 500626.6 & 33.2 & 195176.5 & 13.0 & 1506714.4 & 100.0 \\
\hline 2013 & 67084.0 & 4.6 & 721354.0 & 49.3 & 473084.1 & 32.3 & 201935.2 & 13.8 & 1463457.3 & 100.0 \\
\hline \multicolumn{11}{|c|}{ Belarus } \\
\hline 2018 & 7303.7 & 5.1 & 71210.5 & 50.0 & 24123.8 & 16.9 & 39917.7 & 28.0 & 142555.7 & 100.0 \\
\hline 2017 & 5697.1 & 10.0 & 44372.3 & 77.8 & 6935.0 & 12.2 & - & - & 57004.4 & 100.0 \\
\hline 2016 & 3017.3 & 5.9 & 42104.4 & 82.0 & 6215.1 & 12.1 & - & - & 51336.8 & 100.0 \\
\hline 2015 & 1201.7 & 1.4 & 45199.5 & 53.6 & 10635.4 & 12.6 & 27254.8 & 32.3 & 84291.4 & 100.0 \\
\hline 2014 & 454.6 & 1.3 & 17375.2 & 48.1 & 14821.6 & 41.0 & 3472.6 & 9.6 & 36124.0 & 100.0 \\
\hline 2013 & 414.3 & 0.7 & 48334.6 & 76.5 & 14460.3 & 22.9 & - & - & 63209.2 & 100.0 \\
\hline \multicolumn{11}{|c|}{ Russia } \\
\hline 2018 & 126665.6 & 23.9 & 124192.1 & 23.4 & 261336.2 & 49.2 & 18503.1 & 3.5 & 530697.0 & 100.0 \\
\hline 2017 & 80674.3 & 23.5 & 109436.5 & 31.8 & 137812.5 & 40.1 & 15763.4 & 4.6 & 343686.7 & 100.0 \\
\hline 2016 & 302384.1 & 47.4 & 110382.5 & 17.3 & 224549.3 & 35.2 & - & - & 637315.9 & 100.0 \\
\hline 2015 & 248897.4 & 33.1 & 167273.1 & 22.3 & 317601.8 & 42.3 & 17551.6 & 2.3 & 751323.9 & 100.0 \\
\hline 2014 & 217331.5 & 32.3 & 104010.5 & 15.5 & 337845.8 & 50.2 & 13971.3 & 2.1 & 673159.1 & 100.0 \\
\hline 2013 & 170408.6 & 45.3 & 66353.5 & 17.6 & 118903.2 & 31.6 & 20401.7 & 5.4 & 376067.0 & 100.0 \\
\hline
\end{tabular}

Source: Author's own elaboration based on Yearbooks of Foreign Trade Statistics of Poland of the period 2014-2019 [GUS 2014, 2015, 2016, 2017, 2018, 2019].

in 2013 to some $35 \%$ in 2018 . Throughout the entire research period, food preserves accounted for about $30 \%$, and their share tended to vary. However, the import of live animals and animal products gradually increased - from $5 \%$ to $12 \%$, and the import of oils and fats - from $13 \%$ to $22 \%$. To sum up, in the case of Ukraine during the period under consideration there was a decrease in the share of plant products as well as an increase in the share of food preserves and fats.

Both in the case of Russia and Belarus the value of the registered import of food products in 2018 was higher than in 2013. However, as regards Belarus there was a steady upward trend, whereas for Russia the years 2013-2016 were the period of the most dynamic changes, and this value declined. In the imports from Belarus, plant products had the largest share in the trade pattern (from over $70 \%$ in 2013 to about $50 \%$ in 2018 , and to more than $80 \%$ in 2017). Of the remaining groups of goods, food preserves were of significant importance (over 10-15\%), but their share declined over the whole period under study. Live animals and animal products were relatively the least important. In the structure of the registered import of food products from Russia, two groups of goods were of great importance: animal products and live animals, as well as food preserves. The share of the first of the above-mentioned 
Powęska, H. (2020). The share of cross-border shopping in Poland's trade turnover of food products with neighbouring countries on the European Union eastern border in 2013-2018. Acta Sci. Pol. Oeconomia 19 (4), 103-112, DOI: 10.22630/ASPE.2020.19.4.46

groups of goods systematically decreased (from $45 \%$ to $24 \%$ ), while the share of the second group grew (from $31 \%$ to $49 \%$ ). Plant products were of minor importance; however, the steady growth of this group of goods was worth noting (from $17 \%$ to $23 \%$ ) in the structure of imports of food products from Russia to Poland.

\section{CONCLUSIONS}

As a result of the analysis conducted in the study, it was found that over the period 2013-2018 the international trade in food products between Poland and its eastern neighbours underwent significant changes. However, some similarities were noted in the Belarusian and Russian direction, whereas trade in food products with Ukraine had a distinctly different character. Exports in absolute values (both registered and unregistered sales) of food products from Poland to the Russian and Belarusian markets in the years 2013-2018 were much greater than the import of food products from these countries. However, in the case of Ukraine, in the early years of the research period exports exceeded imports, whereas from 2014 onwards, the reverse trend was observed and the import of food products from Ukraine exceeded exports. This tendency continued until the end of the period under consideration. There was also a steady increase in unregistered trade contacts on the border with Ukraine, and a decline in these contacts on the Russian and Belarusian border sections was noted. Regardless of the absolute values, in the case of all three countries there was a steady increase in the share of unregistered trade in the total volume of trade turnover throughout the whole research period.

When comparing the period 2013-2018 with the years 2010-2012, some similarities should be noted with regard to the Polish trade turnover with neighbours located on the eastern side of the EU border. First of all, there was a continuation of the trend showing that the export (comprising registered and unregistered sector together) of Polish food products to the Russian and Belarusian markets was much greater than the import of food items from these countries. However, in trade with Ukraine, differences in the values of imports and exports were smaller, whereas in the case of Russia and Belarus exports definitely exceeded imports, which was recorded both in the registered and unregistered sector.
The trend regarding the absolute value of unregistered food purchases made within the cross-border trade in Poland also changed. During the period 2013-2018, the value of purchases made by Belarusian citizens increased, while the value of purchases made by Ukrainian and Russian consumers decreased. On the other hand, in the years 2010-2012, there was an increase in the absolute value of purchases of food products made by the citizens of all three countries in Poland, and the value of unregistered purchases of food products made by Polish citizens in the neighbouring countries declined. This trend continued for Russia and Belarus, while in Ukraine in the years 2013-2018 Polish cross-border shoppers bought more and more goods.

All in all, in the years 2013-2018 trade turnover of food products between Poland and its neighbouring countries on the external border of the European Union was an important element of Poland's international trade. Registered turnover had an impact on Poland's economy, whereas from the point of view of the development of areas located in the border impact zone the unregistered turnover that was part of cross-border trade played an important role.

\section{REFERENCES}

Baruca, A., Zolfagharian, M.A. (2015). Cross-Border Shopping: Mexican Shoppers in the US and American Shoppers in Mexico. [In:] D.R. Deeter-Schmelz (Ed.), Proceedings of the 2010 Academy of Marketing Science (AMS) Annual Conference. Springer International Publishing.

Bygvra, S. (2019). Cross-border shopping: Just like domestic shopping? A comparative study. GeoJournal, 84, 497-518.

Cyrek, M., Cyrek, P. (2019). The Benefits of European Integration in the Opinion of Sub-Carpathian Food Retail Trade Entrepreneurs. [In:] J. Dušek et al. (Eds.), Kauzalita rozvoje obcí a regionů z pohledu integračních procesů, daňové politiky a cestovního ruchu. Vysoká škola evropských a regionálních studií, České Budějovice, 56-66.

Dudziński, J. (2006). Handel zagraniczny. Wybrane problemy. Difin, Szczecin.

Egresi, I., Arlstan, S. (2016). Shopping and Tourism in Turkey: The Perfect Combination. [In:] I. Egresi (Ed.), Alternative Tourism in Turkey. Springer International Publishing, 211-228.

Główny Urząd Statystyczny (2014). Rocznik Statystyczny Handlu Zagranicznego 2014 [Yearbook of Foreign Trade Statistics of Poland 2014]. Warszawa. 
Powęska, H. (2020). The share of cross-border shopping in Poland's trade turnover of food products with neighbouring countries on the European Union eastern border in 2013-2018. Acta Sci. Pol. Oeconomia 19 (4), 103-112, DOI: 10.22630/ASPE.2020.19.4.46

Główny Urząd Statystyczny (2015). Rocznik Statystyczny Handlu Zagranicznego 2015 [Yearbook of Foreign Trade Statistics of Poland 2015]. Warszawa.

Główny Urząd Statystyczny (2016). Rocznik Statystyczny Handlu Zagranicznego 2016 [Yearbook of Foreign Trade Statistics of Poland 2016]. Warszawa.

Główny Urząd Statystyczny (2017). Rocznik Statystyczny Handlu Zagranicznego 2017 [Yearbook of Foreign Trade Statistics of Poland 2017]. Warszawa.

Główny Urząd Statystyczny (2018). Rocznik Statystyczny Handlu Zagranicznego 2018 [Yearbook of Foreign Trade Statistics of Poland 2018]. Warszawa.

Główny Urząd Statystyczny (2019). Rocznik Statystyczny Handlu Zagranicznego 2019 [Yearbook of Foreign Trade Statistics of Poland 2019]. Warszawa.

Główny Urząd Statystyczny, Urząd Statystyczny w Rzeszowie (2014). Ruch graniczny oraz przepływ towarów i usług na zewnętrznej granicy Unii Europejskiej na terenie Polski w 2013 roku [Border traffic and movement of goods and services at the European Union's external border on the territory of Poland in 2013]. Warszawa-Rzeszów.

Główny Urząd Statystyczny, Urząd Statystyczny w Rzeszowie (2015). Ruch graniczny oraz wydatki cudzoziemców w Polsce i Polaków za granicą w 2014 roku [Border traffic and movement of goods and services at the European Union's external border on the territory of Poland in 2014]. Warszawa-Rzeszów.

Główny Urząd Statystyczny, Urząd Statystyczny w Rzeszowie (2016). Ruch graniczny oraz wydatki cudzoziemców w Polsce i Polaków za granicą w 2015 roku [Bor- der traffic and movement of goods and services at the European Union's external border on the territory of Poland in 2015]. Warszawa-Rzeszów.

Główny Urząd Statystyczny, Urząd Statystyczny w Rzeszowie (2017). Ruch graniczny oraz wydatki cudzoziemców w Polsce i Polaków za granicą w 2016 roku [Border traffic and movement of goods and services at the European Union's external border on the territory of Poland in 2016]. Warszawa-Rzeszów.

Główny Urząd Statystyczny, Urząd Statystyczny w Rzeszowie (2018). Ruch graniczny oraz wydatki cudzoziemców w Polsce i Polaków za granicą w 2017 roku [Border traffic and movement of goods and services at the European Union's external border on the territory of Poland in 2017]. Warszawa-Rzeszów.

Główny Urząd Statystyczny, Urząd Statystyczny w Rzeszowie (2019). Ruch graniczny oraz wydatki cudzoziemców w Polsce i Polaków za granicą w 2018 roku [Border traffic and movement of goods and services at the European Union's external border on the territory of Poland in 2018]. Warszawa-Rzeszów.

Powęska, H. (2014). The share of cross-border shopping in Poland's trade turnover of food products with the neighbouring countries on the EU's external border. Acta Scientiarum Polonorum. Oeconomia, 13 (4), 147-155.

Powęska, H. (2016). Handel przygraniczny w warunkach zmian przenikalności granicy. Wydawnictwo SGGW, Warszawa.

Rymarczyk, J. (2017). Handel zagraniczny: organizacja i technika. Polskie Wydawnictwo Ekonomiczne, Warszawa.

\section{UDZIAŁ HANDLU PRZYGRANICZNEGO W OBROTACH HANDLOWYCH ARTYKUŁAMI ŻYWNOŚCIOWYMI POLSKI Z KRAJAMI SĄSIADUJĄCYMI NA ZEWNĘTRZNEJ GRANICY UNII EUROPEJSKIEJ W LATACH 2013-2018}

\section{STRESZCZENIE}

Obroty handlowe artykułami żywnościowymi między Polską a krajami sąsiadującymi na zewnętrznej granicy Unii Europejskiej (Ukraina, Białoruś, Rosja) stanowią istotny element międzynarodowej wymiany handlowej naszego kraju. Rejestrowane obroty miały wpływ na gospodarkę Polski, z punktu widzenia rozwoju obszarów położonych w strefie oddziaływania granicy ważną rolę odgrywały obroty nierejestrowane dokonywane w ramach handlu przygranicznego. Celem artykułu jest zbadanie dynamiki i tendencji zmian w zakresie udziału handlu przygranicznego w globalnych obrotach handlowych artykułami żywnościowymi z wymienionymi krajami w latach 2013-2018. W wyniku przeprowadzonej analizy przypadku wszystkich trzech krajów odnotowano stały wzrost udziału handlu nierejestrowanego w ogólnej puli obrotów handlowych przez cały okres badawczy.

Słowa kluczowe: artykuły żywnościowe, handel przygraniczny na wschodniej granicy Polski, handel zagraniczny 